\title{
EDUCATION AND CULTURE FROM LUCIAN BLAGA'S VIEWPOINT
}

\author{
Elena Marilena Năstase (Mihail) \\ Ms. Phd., University of Pitești, ROMANIA, elenamarilena2008@gmail.com
}

\begin{abstract}
Education is a broad concept, having intellectual, moral, social and political values, in order to prepare man for his integration into society, to develop his harmonious personality. Formal education is done in schools, constituting the most favorable environment to learn communication, more precisely to form the ability to talk to others, to think clearly and logically. On the other hand, informal education, along with extra-formal education, complements the communication skills. The present study aims to illustrate the relationship between education, culture and civilization according to the writer and the man of culture, Lucian Blaga. His remarkable personality used to capture the students in the hall of the University of Cluj, which specifically formed for him the Department of Philosophy of Culture. Continuing the ideas from the work Horizon and Style, Blaga upholds in The Genesis of Metaphor and The Meaning of Culture, a different vision of culture. If some Western thinkers consider it a living organism, having all the specific stages (birth, growth, flowering, fruiting, aging and death), the Romanian philosopher gives it an original perspective. The current study develops this conception, by differentiating minor culture from the major one. Lucian Blaga draws the attention to the fact that the forms of minor culture are not related to the organic temporality, because the "childish" feature of minor (ethnographic) culture has no age. Major (monumental) culture does not need an earlier stage. The metaphor and the myth contribute to the fulfillment of cultural creations. They are the consequence of ontological mutations, of placing man in the horizon of mysteries. The stylistic matrix falls into the category of "transcendent constraints" through which The Great Anonymous restricts human spontaneity in order no to reveal the mysteries of the world. In Lucian Blaga's vision, "civilization" would represent the winter stage of a culture. The elements of civilization are not revealing, but they become utilitarian. The study also brings to the foreground the antonymous relationship between culture and civilization, critically illustrated from the perspective of Oswald Spengler, H. St. Chamberlain, Nietzsche. From Lucian Blaga's viewpoint, the educational process manifests itself throughout life, being in connection with the stylistic matrix, with the cultural activity.
\end{abstract}

Keywords: education, culture, stylistic matrix, civilization.

\section{INTRODUCTION}

Lucian Blaga's work contains elements and structures that reflect the relationship with education in the broad sense of the term. The poet and the philosopher Lucian Blaga, kept a deep silence until the age of 4 , an aspect that could have been misinterpreted from an educational point of view, as a cognitive, psychological incapacity. Now, in the century of transformations, of educational and cultural progress, Howard Gardner gives the Theory of Multiple Intelligences. The absence of words, in the case of the Transylvanian writer, represented, on the one hand, a form of defense against unwanted circumstances, and, on the other hand, it defined the return to the embryonic state, correlated with the original nostalgia.

Blaga's genius could have been classified in the eight types of intelligence widely debated by the Harvard professor.

The Romanian writer manifested his linguistic intelligence through his sensitivity for the meaning, the sonority of words and for the rhythms of the the language (Howard Gardner, 2006, p.13). It is worth 
mentioning here the use of metaphors in his literary language. For exemple, the lyrics of the poem Three Faces: The child laughs: My wisdom and my love is play!/The young man sings: My wisdom and my play is love!The old manis silent: My love and my play is wisdom!

The word games (puns), the deductive and inductive thinking skills, the critical ability, they all prove his logical-mathematical intelligence(idem, 2006, p.11). The sensitivity to tonality, to the music of the spheres, is found in Blaga's Orphic myth, whilw the imagination of cosmogony, with its musical harmony, demonstrates his spatial intelligence. In the same order of ideas, his dramatic plays are also a proof of the Romanian playwright's capacity to imagine the movement of the actors on the stage, their gestures (for example, the plays Zamolxis, A pagan Mystery, his unique pantomime-Resurrection).

Last, but not least, we must draw attention to Blaga's permanent involvement in the educational domain(he was the founding member of the Gândirea magazine-1921), in the academic field (he was a member of the Romanian Academy, his reception speech being The Praise of the Romanian Village, in 1973). Also, he took part in a cultural exchange during the time when he was a Romanian diplomat in Warsaw, Prague, Bern and Vienna.

\section{STYLISTIC MATRIX}

The classical culture, assimilated during the school period, was the basis of Blaga's professional training, imprinting the responsibility of culture in promoting the value of the Romanian people, of the stylistic matrix, of the style. The latter play an essential role in defining metaphor, the expressive form of the relationship of the Transcendent with the immanent. This can also be easily noticed in Lucian Blaga's statement: style (and culture as a set of styles) is the result of multiple, discontinuous factors of categorical expression, which, by mixing and sometimes by their interference, constitute a stylistic matrix, with the nest in the human unconscious. (Lucian Blaga, 1985, p.43). Structured in an ontological dualism, man is placed on the horizon of mystery which tries to reveal itself through these concepts as well. Included in the transcendent constraints, the abysmal categories and the stylistic matrix are a kind of barriers imposed on man and his creative spontaneity in order to never be able to positively-adequately reveal the mysteries of the world (Idem, 1985, p.181). According to Blaga's philosophy, what defines a cultural creation is metaphor, and its function applies not only to the representation of art, but also to others, such as the metaphysical, scientific or religious one (Eugeniu Nistor, 2020, p.272). The human being goes beyond the animal stage, becoming a metaphorizing animal, as stated by the Romanian thinker, who thus supports his statement: The emphasis we want to put on the metaphorizing epithet is almost intended to suppress animality, as a definition. This would mean that in the genesis of metaphor we must see an outbreak of human specificity in all its magnitude (Lucian Blaga, 1985, p.41). Blaga's metaphor is defining for the anthropological plan, or, as Blaga says, it is definitely related to the structural order of the human spirit (Ibidem, p.352). This trope exceeds its stylistic value, becoming an instrument of philosophical creations. It also reminds of Plato or Aristotle who appealed to metaphor as a way of rethinking the world (Aristotel, 1965, p.85).

The term "style" constitutes the totality of features determined by factors that act unconsciously on human communities. Style is established without wishing to do so, without knowing it; it partially enters into the light cone of consciousness, as a message from the empire of over light, or as a magical creature from the great and dark tale of earthly life (Lucian Blaga, 1985, p.72). In Blaga's case, we are not wrong to say that style is a metaphysical instance which mediates between the historical and the trans-historical dimension of man (Ion Goian, 1987, p.351). Among the unconscious key elements there are: the spatial and temporal horizon, the attitude towards them (axiological accents), the anabasic (the advance in the horizon), the catabasic (the retreat from the horizon) and the formative longing.

The stylistic matrix is like a bundle of categories, which is imprinted, unconsciously, on all human creations and even life, as it can be shaped by spirit (Lucian Blaga, 1985, p.177). Style isolates us from mysteries, insofar as it brings us closer to them (Dumitru Micu, 2003, p.280). It is precisely because all the objects of knowledge have a hidden side that the metaphor is called upon to increase the revelation, not to darken, through catharsis phenomena, the background of the objects, which Blaga considers to be revealed signs of some mysteries.

The time of the fountain is the time of the future while the time of the waterfall corresponds to the emblematic past of humankind. It occurs in Hebraic culture and religion, in the evolutionary conception, which aims to gradually evolve from imbalance to equilibrium. The present coincides with the time of the river. Within it, a permanent passage of equal moments is identified. These temporal and spatial horizons define us, despite the fact that we are not aware of them (Lucian Gruia, 2013, p.60). In terms of space and time horizons, we can create an anabasic or catabasic attitude. The first is trust in life, the desire to conquer, and the other 
expresses the withdrawal from the horizon, non-violence (Geo Săvulescu, 2000, pp. 22-23).These result from the way in which man relates to the trajectory of life.

Formative longing reflects individual longing, as well as typical and elemental aspirations. The individual longing, based on Leibniz's Monadology, indicates the idea that each monad constitutes a kind of spiritual atom, an atom of being. The typical aspiration was developed by the ancient Greeks, by following some rules, as Sophocles, Plato, and later Racine, Goethe, in the Renaissance, will do. The elemental aspiration, "stoiheion" for the Greeks, the basic aspiration, in which the elements are unleashed like a flood, is a force of nature that you cannot oppose. We find it in Ancient Egypt, in the art of Byzantium, in India (Petre Mihai Gorcea,1995, pp. 39-41).

The typifying and individualizing modes correspond to human creation, having the imprint of freedom, while the elemental mode corresponds to the divine creation, under the influence of the necessary.

This statement by Petru Mihai Gorcea, restates the influence of the elemental dimension on the lyrical work (The Light, Give Me a Body You Mountains, The Death of Pan, Silence, Disintegrating Paradise, The Daughter of the Earth plays, Ecstatic Night, The Great Burning, The Old Saint George, The Marvellous Seeds - ) (Ibidem). It should be emphasized that the elemental message finds its correspondent in Blaga's double self-portrait, as Axente Creangă and as Leonte Pătrașcu, in Caron's Boat - Luntrea lui Caron, as well as in his dramatic characters. Nothing is new so far, however, the Transylvanian writer emphasizes the fact that the choice of one of the specified methods depends on the creative forces of the collective unconscious. The Romanian philosopher increases its importance also in relation to the time and space enciphered in us.

Blaga develops his ideas about "the mioritic space" in the Trilogy of Culture. The undulating space horizon, shaped by the hill-valley, is in solidarity with the Romanian soul. This space, finely discovered, exaggerates the correspondences and analogies in the swaying prosody of doinas, in the courtyards and gardens which, as some unaccented syllables, separate the houses from the village. Related to the mioritic space can also be the feeling of longing, the state of mourning. Longing is considered firstly as a whirling state of mind, as a hypostasis, then it is seen as an impersonal power, devastating and subjugating, sometimes as a moving spell, sometimes as a cosmic disease, as an invincible element of nature, as an alter ego, as a materialspiritual emanation of the individual (Lucian Blaga, 1985, p.219).

Dumitru Micu notices the Sofian approach which is representative of oriental (and Romanian) spirituality through the descending transcendence, as in Mioriţa. Here, nature is transformed into a church. Man and the space of this temporal world can become a vessel of that transcendence. In his theory on the Sofian approach, exposed in The Mioritic Space, Blaga reminds the Russian sophologists: Berdyaev, Bulgakov, Florenski. Blaga's Sophian perspective does not emphasize the substantiality and coessentiality of divine wisdom, like the Russian theologians, but its action. A suitable term for Blaga's "ontological mutation" is Berdyaev's anthropological revelation. Occurred in neo-gnosticism, the age of the Holy Spirit is the age of the creative man, the age succeeding the age of the Father and that of the Son embodied in history (Nikolai Berdiaev, 1992, p.36).

The anthropological revelation is the discovery of man in (as) God. For the Romanian thinker, "the superior, theurgical magic" forms the core and environment of cultural creativity, while for the Russian thinker, theology defines the artist from the era of the anthropological revelation. The difference lies in the fact that, in Blaga, man completes himself as a demiurge, while, within the scope of Berdyaev's anthropological revelation, God is the one who completes himself as a man. Creative existence (in Blaga) and creation as "human justification" (Berdyaev) represent the common aim of the two apologies. Opaque to the inspiration of the Holy Spirit, Blaga's creator does not close himself to the divine emanations of some "cosmic potencies", to" grace and magical miracles". On the contrary, the writer seeks to obtain the latter through the poetic word, a descendant of the original words, as a theorist of language. Thus the poet reaches "the song that consumes matter or the one that raises the being over time, through purifying burning."

According to Professor Dumitru Stăniloae, style is linked to religion in search of the highest level of reality. Style hinders knowledge of reality, being a concealment of it. While the Great Anonymous urged us to know the Truth, yet, through transcendent censorship, he denies it to us (Lucian Blaga, 1983,p.203). Ion Goian expresses the same idea of placing the man in a position secondary to the Great Anonymous, eliminating man's possible creative competition and deepening the demon of the Great Anonymous (Ion Goian, 1987, p.348). Man's religiosity, as a desire of the Absolute, becomes his impulse. Professor Stăniloae claims that our religious and metaphysical manifestations are not exclusively the product of the stylistic matrix, but the deeper yet deviated impulse of our being according to reality (Dumitru Stăniloae,1993,p.17) This vital impetus does not come from the sacred, but from the metaphysical dimension, as Blaga would argue. Actually, his 
religious perspective is a mixture between Feuerbach's theory and Spencer's positivist. Thus, religion is the result of fantasy, it is a myth. Although it contradicts Blaga's vision, the Romanian theologian firmly maintains his opinion, showing how religion differs from science, art or metaphysics. Metaphysics participates predominantly or exclusively through knowledge in the order that man reveals to himself. Through religion, the human being totalises itself in front of the order that reveals to itself, that is, the human being participates in the order in question with knowledge, with affects (Lucian Blaga, 1942, pp.180-181).

Blaga goes on to clarify the definition of religion, in Religion and Spirit, as a subjective endeavor of selftotalisation and self-transcendence of the human being, ideally correlated with the latest elements or coordinates of the existential mystery in general, which man reveals or considers them revealed (Idem,1942, p.178). The philosopher turns out to be agnostic when he considers Jesus Christ a simple man, deified by people, recognizing that he has only a "superhuman power" (Ibidem, p.144).

The image of the Great Anonymous reminds us of God - The Father, lahve, from Martin Luther's doctrine. His intolerance illustrates his jealousy of people who are saved only by faith. Luther even combats Aristotle's Ethics, showing that goodness has never saved the soul. He underlines the experience of faith in oneself, "a naive and total trust, such as that of children (Mircea Eliade,1988, pp. 253-254). Blaga was certainly aware of this concept when he wrote the dramatic plays Zamolxis and The Children's Crusade. He was also familiar with shamanic practices, specific to Dacian prehistory. The shamanic ritual included therapeutic invocations and suggestive healing. In Zamolxis a cathartic ritual takes place, the wizard driving away the spirits.

Shamanism is par excellence a religious phenomenon, in which initiation involves the breaking of the body, the renewal of organs and viscera and the ritual death followed by resurrection, experienced by the future shaman as a descent into Hell (sometimes accompanied by ascension). The shaman is an ecstatic par excellence. Or, at the level of archaic and traditional religions, ecstasy means the raising of the soul to heaven or the pilgrimage to earth, or, finally, the descent into underground regions, among the dead (Mircea Eliade,1986, p.55) In Whirling Waters, a sacrifice takes place by substitution, the Old Man being killed instead of the Priest.

We can point out, along with Geo Savulescu, that Blaga qualifies the stylistic matrix as a priori: by admitting with Kant that the various categories that constitute the world of our knowledge are subjective moments of the human spirit we will be even more entitled to accept this view regarding the abysmal categories, which determine the world of creations.

Abysal categories are accusatively subjective factors. There is, in other words, not only a cognitive a priori, but also an abysmal, abysmal-stylistic a priori (Geo Savulescu,2000, pp28-29). In line with these ideas, we recall Blaga's original view on archetypes and stylistic factors. Archetypes have their origin in the instinctive, restricted side, specific to the collective or absolute unconscious, based on ancestral experiences. Jung admits a kind of hereditary memory, through which the archetypes would be transmitted from generation to generation (Lucian Blaga, 1976, p.168). Therefore, the archetypes render the general human level of the collective unconscious, while the stylistic factors vary depending on the era, the community, the individual.

The collective unconscious would store various archetypes, including animus and anima. In other words, stylistic factors characterize the creation of culture, which does not exist in the animal world. Several differences reflect the essence of the two categories: while the stylistic factors have a role in shaping the human spirit, the archetypes are of general value, as ways to adapt to the sensitive world. Also, archetypes connect man with nature, while stylistic factors give them the quality of a historical being. A stylistic field and an exchange between the individual and history are created, the individual being able to creatively modify the objective stylistic field (Ibidem, pp. 172,175). At the same time, stylistic factors will not need transformation to reach consciousness. Their way of manifestation will be personance (personanța) closely related to the unconscious, a process thanks to which certain unconscious contents appear in consciousness low as echoed, but not disguised (Lucian Blaga,1969, p. 27).

Blaga further explains his notion (personanța): Without the reflexes received from the unconscious, consciousness would be devoid of form and depth...Without the personances of the unconscious, conscious life would probably gain in precision of lucidity, but would lose plasticity. The unconscious lends to infinite consciousness a vague feature, restlessness, contradictions and stratification, obscurities and penumbras, namely perspective, character and a multidimensional profile. It manifests itself in spiritual and artistic creation, according to the philosopher (Ibidem, pp. 31-32).

The vision of spirit-soul dualism and the collective unconscious separates Blaga from Freud (the superego). For the German philosopher, the spirit derives from the soul having with it only an energetic relationship. 
Freud equates archetypes with the spiritual side of the unconscious, but differentiates them from stylistic factors. Thus, Blaga rejects the explanation of spiritual creation, either a work of art or philosophical system, from the perspective of the unconscious soul (repressed instinctual contents), a reductionist explanation and will oppose the explanation of spiritual products by unconscious stylistic factors, which give content to a deep spiritual structure, called by the Romanian thinker stylistic matrix (Vasile Dem Zamfirescu,1987, pp. 415-416)

Comparing the concept of the stylistic matrix with Levi-Strauss's structuralism (the semantic structure of myths), we identify the same noological conception of the unconscious as an instance of structure, in the value and evolutionary equivalence of prehistory and history, of minor and major cultures that can make the two philosophies part of a common morphological rationality paradigm (Aurel Codoban, 1987, p.419). However, if for the French semiologist the meaning comes form the communication process, for Blaga knowledge is essentialized by mystery. Thus, the category of the significant dominates the rational (Ibidem, pp. 422-423)

\subsection{Culture and Civilization}

The philosopher, Lucian Blaga, also makes the necessary reference of man to culture, culture to style, and style to the stylistic matrix. It can be placed, up to a point, close to the theory of the collective unconscious. But Blaga sees it as a generating source that can enrich or reveal a universe, not as a transcendental wisdom, which guides the world. Denying divine revelation, Blaga believes that all religions are always under the rule of the stylistic categories of the human spirit, submitting to them with the same docility as all manifestations of culture (Lucian Blaga, 1942, p.188)

His metaphysical vision leads him to the conclusion that everything that the Great Anonymous reveals to us in a positive way is disguised, while he also said that what he reveals to us in an undisguised manner is done in a negative way; thus, he joins the revealing functions of metaphor with the censored functions of the stylistic matrix: metaphor and style are distinct aspects of the creation of culture (idem,1997, pp33).

Before creating his own philosophy of culture, Blaga considered that the spiritual needs of our nation are at the core of it. Our philosophy at the beginning cannot therefore be metaphysical; fatally it must be a philosophy of culture (Lucian Blaga, 1973, p.46).

The distinguished philosopher had researched European cultures, Greek culture, Indian culture, Arabic culture, their styles, a fact proved in the work Horizon and Style. Thus, he came to invoke the importance of the indigenous background of our nation, following the model of Eliade who had documented the resistance of the pre-Aryan fund in Hindu culture.

From Blaga's perspective, childhood and maturity must be seen as possibilities for producing the stylistic matrices that give rise to minor (ethnographic) cultures and major (monumental) cultures: the minor or major aspect of creators or community, and not a real age problem on the part of creators, on the one hand, or on an alleged organic subject of culture, parasitic superimposed on man on the other hand (idem, 1985, p.346). Therefore, Blaga does not refer to the organic temporality, but to the adoptive, spiritual ages: Childhood, as the adoptive age of community and creators, gives rise to minor cultures; maturity, as the adoptive age of community and creators, gives rise to major cultures. Within cultures, man becomes creative only by pretending, in a certain way, again as a child. In adult cultures, man becomes creative only by adopting a mature mentality, even if he happens to be a child, like Joan of Arc, Mozart, or Rimbaud. Minor culture and major culture can therefore be explained by the phenomenon of collective psychology of adoptive age.(ibidem).

The minor culture has in its center the world of the village, while the major culture reveals the world of the city. The admiration for the spiritual richness of the village is obvious: a settlement of people, it is a community included in the interior forms of a stylistic matrix, but its entire style is achieved form the point of view of autonomous childhood structures (ibidem, p.340).

The Romanian thinker emphasized the different conceptions regarding culture and civilization. Thus, the English historian H.St.Chamberlain understands by culture the creations of the human spirit in spiritual fields (metaphysics, religion, art), and civilization is all the goods and preparations, ordinances and interventions related to the material life of mankind. Science, close to both, would occupy an intermediate position (ibidem, p.400)

A close perspective is also seen in Oswald Spengler, but once a soul culture has finally reached its peak of flowering, it would be transformed under the empire of a fatality into material civilization (ibidem). Blaga believes that, although it is an achievement of the human spirit, the creation of civilisation is good for comfort and well-being. 
The Spenglerian philosophical system, which borrows Nietzsche's trajectory, will also influence Blaga's conceptions. In Spengler's ideas, the Apollonian appears as a principle of limiting individualization and timeless presence. The Dionysian is eliminated by a dogmatic case, specifically Spenglerian, from the explanation of ancient culture, being introduced in the form of the Faustian, characterized by the principle of infinity, tension, chiaroscuro(ibidem,p.401).

The discontinuity of cultures present in Spengler was also observed in Blaga's conception of culture:If in culture spiritualism emphasizes the motive of ideality, and idealism underlines that of dynamic continuity, realism accentuates that of anthropological objectivity, Blaga's philosophy wants to highlight especially the motive of creative discontinuity, organic individuality and perhaps precisely in this intention lies its greatest merit (Banfi, 1967, p.130).

There are ontological differences between culture and civilization, culture responds to the existence of selfpreservation, and civilization responds to the requirement of self-preservation and security. We radicalize the distinction between culture and civilization, giving it ontological proportions (Lucian Blaga, 1985, p.402).

Blaga rejects the landscape as a determining factor of culture, a Spenglerian theory, on the issue raised in The Original Phenomenon( Lucian Blaga, 1925, p.79). He preserves the symbolic interpretation of the phenomena, yet different from the link that could be between the original symbol of a culture and the landscape in which it is located.

In Horizon and Style, Blaga pointed out that spatial vision can be a defining element of culture, but not a source, and fought against the wrong theory of the cultural soul. Thus, while Blaga took advantage of the ideas of the morphology of culture, in particular Spenglerian, opposing the unique origin of space, he developed his own theory of culture, in connection with both our philosophy in general and the folk material, so abundant and enlightening, of our people(idem, 1985, p.139).

In this respect, Corin Braga observes the transposition of the folkloric background of the author's childhood in the mythology of the Geto-Dacians.The morphological category of communion with nature, which is essential in shaping the ethnic matrix of the Romanians, is unconditionally attributed by Blaga to the stylistic matrix of the Thracian civilization as well. The Geta, as a forest man, of course, also had forest deities. The forest was for him a palpable, magical-protective deity. The Geta, when entering the forest, felt entering the divinity. The Celt had mothers, protective beings of the house, of the household. The Romanians still know today a mother of the forest, at least in stories. Even if this mother of the forest is not an archaic remnant, it is permissible to suspect behind some Atari figures throbbing a depth of mythology and magic of the forest, a Geto-Dacian depth.(Corin Braga, 1998, pp179-180)

Tertullian identified the same exaltation in Nietzsche, that of the barbarians, the same preservation of the instincts of the Nordic peoples, as in Blaga, since the Dacians of Zamolxis appear as personifications of nature, with an existence outside moral notions and social imperatives, like the Titans of that extraApollonian world evoked by Nietzsche (N.Tertulian, 1968, pp.181-182). Tracomania, which appeared in the nineteenth century, as a romantic reaction to the exaggerations of the Latin school, will push the Romanian philosopher to explore the local background (Ovidia Babu-Buznea, 1979,pp38-39). The writer will praise it in The Revolt of our Non-Latin Background, noting that in general, historians, either Romanians or foreigners, are increasingly inclined to look at Romanians as a dominant Thracian people (Getica, 1972, p.76). Mircea Vaida noticed that the Thracians are placed by Blaga under the sign of the hearth, corresponding to the writer's childhood in his native village, while the Romans have as emblem the road, Via Appia, corresponding to the urban destiny of the writer, who entered the great journey of life (Mircea Vaida, 1982, pp.109-115).

Mircea Eliade confirms that the Geto-Dacian branches of the Thracians knew both the Dionysian orgiastic cult and the Orphic mysteries (Mircea Eliade, 1988, p.233). The same vision of the immortal soul and of the body that prevents it is shared by the Geto-Dacians, but also by the Orphics, the Pythagorean and Platonic systems. From this perspective, the philosopher will correlate the idea of immortality with magical practices, capable of freeing the soul from the imprisonment of the body. It is then pertinent to refer to Corin Braga when he claims that after the praise brought to the Geto-Dacian fund against Latin culture, he favors the substrate factor (Neolithic or Asian shamanism) over the Indo-European heroic cult (Corin Braga, 1998, p.178).

Through stylistic topography, Blaga outlines the portrait of Dacian spirituality, defined by the boundless horizon, by the defensive affirmation, the geometry and abstract stylization, the magical-active participation in existence, the anthropomorphism, the fulfillment in post-existence (ibidem, p.173). Thus, the Transylvanian thinker refutes the characteristics supported by Vasile Pârvan (monotheism, zoomorphism, uranism). He argues that the Thracian religion was polytheistic and anthropomorphic, as evidenced by 
research (Hadrian Daicoviciu, 1965, p. 168).Corin Braga emphasizes the fact that, instead of uranism, Blaga proposes a cosmic mediatism, to which the Christian Sofianic will correspond, or what Eliade will call cosmic Christianity (Corin Braga, 1998, p.173).

Unlike Vasile Pârvan, Blaga has a predilection for the telluric and the demonic, a tendency also observed by Al. Paleologul (Alexandru Paleologu, 1970, p.86). If Zamolxis is considered a Uranian god by Vasile Pârvan, Gr. Tocilescu and Erwin Rohde, A.D.Xenopol assimilates him to the god of the dead, to the mystical Dionysus. Blaga appeals to the arguments in Getica, stating that it does not result from this that Zamolxis would have been an exclusively luminous and heavenly deity ( Lucian Blaga,1943, p.80).

Blaga supports the image of a Scythian Pan, returning to the non-Latin background, which represents a source of energies. Thus, he equates the Latin layer to the Apollonian principle, and the Thracian and Slavic substratum to the Dionysian principle: It can be said that the dominant feature of the Romanian spirit is Latinity, quiet and, par excellence, cultural. But we also have a rich Slavo-Thracian background, exuberant and vital, which, no matter how much we oppose it, sometimes detaches itself from the corolla of the unknown, rising strongly in consciousness. Latin symmetry and harmony are often shattered by the storm that flashed quietly in the somewhat metaphysical depths of the Romanian soul. It is the revolt of our nonLatin fund (Blaga, 1973, p.48).

\section{CONCLUSION}

In accordance with Emil Cioran, we consider that the one who spoke about the revolt of our non-Latin fund defined the premises of an autobiography. If in Eminescu the Slavic element from the Moldavian soul broke out, in Lucian Blaga what is Germanic in Transylvanian psychology broke out no less (Emil Cioran,1990, pp132,135). This vitalism specific to the Mioritic space, that Romanian energy will also be noticed by Vasile Băncilă(1938, p.21)

Through all his lyrical, dramatic, philosophical and journalistic creation, Lucian Blaga never stopped promoting the Romanian culture, presenting it in a permanent relationship with education and civilization, and always projecting them in a European context. His ethnographic, historical and scientific research, always synchronizing with the European trends of the time, completedhis personality. He was particularly concerned with the artist's creativity, artistic vision, freedom of imagination, synthesis and novelty, finding a supportive background in Brâncuși's world- renowned work. Therefore, any valuable work constitutes an educational tool for young people who are in a continuous development, as well as for adults eager for spiritual and scientific nourishment.

\section{REFERENCE LIST}

Aristotle, (1965), Metaphysics, translation by St Bezdechi, RER, Academy Publishing House, Bucharest

Babu-Bunea, Ovidia,(1979), Dacians in the Consciousness of our Romantics. Sketch to a History of Dacism, Minerva Publishing House, Bucharest

Băncilă, Vasile, (1938), Lucian Blaga, romanian energy, in Romanian Though, Cluj-Napoca

Berdiaev, Nikolai,( 1992), The Meaning of Creation, Attempt to Justify Man, Humanitas Publishing House

Blaga, L. (1985), The Genesis of Metaphor and the Meaning of Culture, in Trilogy of Culture, Minerva, Publishing House, Bucharest

Idem,(1942), Religion and spirit, Dacia Traiana Publishing House, Sibiu

Idem,(1973), The Revolt of Our Non-Latin Found, in The Sand Clock, preface and bibliography by Mircea Popa, Dacia Publishing House, Cluj-Napoca

Idem,(1973), The Sand Hourglass, Dacia Publishing House, Cluj-Napoca

Idem(1925), The Original Phenomenon, Principele CarolCulturalFoundation Publishing House, Bucharest Idem, (1997), Divine Differentials in the Cosmological Trilogy, Humanitas Publishing House, Bucharest

Idem,( 1976), Anthropological aspects, chapter Archetypes and stylistic factors, Facla Publishing House,Timisoara, 
Idem,( 1983), Transcendental censorship in theTrilogy of knowledge, Minerva Publishing House, Bucharest Idem,(1946), The Trilogy of Values, The Foundation for Literature and Art, Bucharest

Idem, (1972), Getica in Izvoade, Essays, Conferences ,Articles, editied by Dorli Blaga and Petre Nicolau, Minerva Publishing House, Bucharest

Banfi, Antonio, (1967), Blaga and Art as Open Revelation, in $20^{\text {th }}$ century, no4,Bucharest

Braga, Corin,(1998), The Praise of the Thracians in Lucian Blaga. The Genesis of The Imaginary Words, The Eupean Institute, lasi

Cioran, Emil,(1990), The Inner Style of Lucian Blaga in Revelations of Pain, Cluj-Napoca

Daicoviciu, Hadrian,(1965), The Dacians, Scientific Publishing House, Bucharest

Gardner, Howard,(2006), Multiple Intelligences, New Horizons, Basic Boos, New York

Micu, Dumitru,(2003) Style and Metaphore in Lucian Blaga. Self-forging by Logos, Constelații Publishing House, Bucharest

Eliade, Mircea, (1988), History of Religious Beliefs and Ideas, translation by Cezar Baltag, chapter Zamolxis and Immortalisation, Scientific and Encyclopedic Publishing House, Bucharest

Eliade, Mircea,(1980), From Zamolxes to Genghis-Han, Scientific and Encyclopedic Publishing House, Ed Bucharest

Eliade, Mircea,(1988), Luther's Theology. Polemics with Erasmus in "The History of Religious Beliefs and Ideas, vol.III, From Muhammad to Age of Reforms, Scientific and Encyclopedic Publishing House, Bucharest

Goian, L. (1987), Opening to Antropolgy in Lucian Blaga-Knowledge and Creation, Cartea Românească Publishing House, Bucharest

Gorcea, Petre Mihai, (1995), Elemental Characters in Blaga's Dramaturgy, in Thought, Feeling and Faith, Magazine of Humanistic Culture, Bucharest

Nistor, Eugeniu.(2020), The Revelation of Metaphor and the Impact of the Mythical Spirit in Lucian Blaga's Philosophy in Discobolul, Culture Magazine, XX, April-May,Alba -lulia

Paleologu, Alexandru,(1970), The Spirit and the Letter.Pseudo-critic Attempts, Eminescu Publishing House, Bucharest

Săvulescu, Geo.(2000), Lucian Blaga.Philosophy through Metaphors, A.B Romania,The Eternal Living Fire, Bucharest

Stăniloae, Dumitru, (1993), Mr.Lucian Blaga's Position on Christianity and Ortododoxy, Paideia Publishing House, Bucharest

Vaida, Mircea, (1982), In The Footsteps of Lucian Blaga, EDI Sport si Turism Bucuresti 